\title{
H. SCHULTINK
}

\section{Output Conditions in Word Formation?}


C Copyright reserved

No part of this book may be translated or reproduced in any form, by print, photoprint, microfilm, or any other means, without written permission from the author.

The text of this article is reprinted from

UT VIDEAM:

CONTRIBUTIONS TO AN UNDERSTANDING OF LINGUISTICS

For Pieter Verburg on the Occasion of His 70th Birthday

pp. 263-72

Printed in Belgium by NICI, Ghent 